\title{
Depresi Menghadapi Pandemi Covid-19 pada Masyarakat Perkotaan (Studi Literatur)
}

\author{
Giofanny F Lempang ${ }^{1 *}$, Wingga Walenta ${ }^{1}$, Khalisa A Rahma ${ }^{1}$, Nova Retalista ${ }^{1}$, \\ Fransiska J Maluegha ${ }^{1}$, Firman I Utomo ${ }^{1}$ \\ ${ }^{1}$ Fakultas Psikologi Universitas Surabaya \\ Jl. Raya Rungkut Kali Rungkut Kota Surabaya 60293 Jawa Timur \\ *Email: fannylempang@gmail.com
}

Naskah diterima 21 Januari 2021, Revisi 15 Maret 2021, Terbit 29 April 2021

\begin{abstract}
DOI: doi.org/10.21107/pamator.v14i1.9854

In the early 2020, there was an outbreak of a disease that attacks the human respiration and is caused by the coronavirus disease. The spread of this virus has an impact on world conditions, especially on the country's social and economic conditions. This is because the government is implementing a lockdown system to prevent the spread of the virus. Some activities are carried out at home because of government regulations for social distancing. However, the existence of these rules makes it difficult for some people to adapt to situations such as doing activities at home and limiting themselves from interacting so that they may be prone to experiencing anxiety which results in depression in society
\end{abstract}

Key words: corona virus disease, depression, social distancing

\section{PENDAHULUAN}

Pada awal Desember 2019 terjadi penyakit pernapasan akut yang dikenal sebagai Virus Corona 2019 di kota Wuhan, Provinsi Hubei, Cina. Wabah COVID-19 mengalami peningkatan setiap harinya dikarenakan penyebaran virus ini terjadi secara cepat melalui kontak langsung antar manusia. Adapun gejala yang dirasakan oleh pasien yang terinfeksi SARS-CoV-2 menunjukkan gejala pada sistem pernapasan seperti demam, batuk, dan dispnea (Susilo dkk, 2020). Virus ini kemudian menyebar dengan cepat ke seluruh belahan dunia sehingga pemerintah berusaha untuk mencari solusi pencegahan penularan COVID-19 (Huang \& Zhao, 2020). Di Indonesia COVID-19 pertama kali terjadi pada awal tahun yaitu sekitar bulan Maret 2020 dengan kasus dua orang pasien. Setelah itu pada akhir Maret 2020 kasus ini meningkat sekitar 1.528 kasus dan 136 kasus kematian (Susilo dkk, 2020). Terjadinya peningkatan kasus yang cukup tinggi, maka pemerintah berusaha untuk menangani pencegahan penyebaran virus dengan skala besar yaitu mengeluarkan peraturan untuk melakukan segala kegiatan di rumah atau disebut sebagai work from home.
Kehadiran wabah COVID-19 saat ini dapat dikatakan memberikan dampak yang negatif terhadap sebagian masyarakat terutama pada masyarakat perkotaan. Menurut Brook (2020) pandemi yang terjadi saat ini mempengaruhi kondisi psikologis masyarakat seperti gangguan stres pasca trauma (post traumatic stress disorder), depresi, cemas, frustasi, insomnia, merasa diri tidak berdaya dan adanya kondisi yang membuat individu merasa ketakutan terinfeksi COVID-19 (Setyaningrum \& Yanuarita, 2020).

Program work from home yang diterapkan sebagian besar mempengaruhi keadaan psikologis individu maupun kelompok sosial. Proses kegiatan secara daring kemungkinan besar menimbulkan rasa jenuh, cemas, stress bahkan depresi. Hal ini dikarenakan beban tugas yang semakin besar tanggungannya dan minimnya waktu pengerjaan ataupun penyelesaian tugas. Beban yang ditanggung semakin berat sehingga memungkinkan terjadinya masalah pada keadaan psikologis, salah satunya yaitu depresi. Selain itu, adanya pemberlakuan peraturan untuk melakukan social distancing yang mana peraturan tersebut seakan membatasi ruang gerak masyarakat untuk berinteraksi yang kemungkinan akan 
mempengaruhi kesehatan mental masyarakat.

Selain melakukan social distancing, sebagian perusahan pun melakukan pemutusan hubungan kerja dikarenakan kurangnya pemasukan sehingga kesulitan untuk membayar tenaga buruh. Tindakan yang dilakukan oleh beberapa perusahaan di masa pandemi saat ini memberikan dampak yang cukup memprihatinkan terutama bagi masyarakat perkotaan karena kehilangan pekerjaan yang membuat mereka kesulitan untuk memenuhi kehidupan diri sendiri juga keluarga (Nesya \& Sarjana, 2020). Ketidakmampuan dari pihak yang di PHK untuk bertahan hidup di masa pandemi tentu akan mempengaruhi kondisi psikologisnya dan kemungkinan menimbulkan stres bahkan depresi. Kesehatan mental merupakan aspek penting untuk mewujudkan kesehatan yang menyeluruh. Namun belum menjadi prioritas pada negara berkembang jika dibandingkan dengan penyakit menular. Di Indonesia, regulasi mengenai kebijakan kesehatan mental dan implementasinya masih terdapat kesenjangan yang luas terkait dengan masalah cakupan dan akses pada pelayanannya (Ayuningtyas et.al, 2018).

Pada studi literatur ini, peneliti menemukan beberapa penelitian yang menjelaskan mengenai kondisi psikologis masyarakat seperti depresi yang diakibatkan oleh COVID-19. Hasil penelitian menunjukkan bahwa gejala depresi rentan terjadi pada masyarakat perkotaan dengan kelompok usia < 35 tahun dan kebanyakan dialami oleh perempuan. Beberapa penelitian tersebut dijadikan acuan untuk menulis studi literatur ini dengan harapan juga dapat berguna untuk penelitian selanjutnya mengenai depresi. Pada masa pandemi ini jumlah kasus depresi semakin meningkat, maka artikel ini bertujuan untuk menganalisis faktor yang mempengaruhi peningkatan depresi di masa pandemi. Artikel ini diharapkan menjadi referensi bagi penelitian selanjutnya.

\section{METODOLOGI}

Metode yang digunakan merupakan metode kualitatif yaitu studi literatur. Penggunaan kedua metode tersebut bertujuan untuk memahami realitas dan makna dari peristiwa yang diketahui melalui hasil penelitian jurnal terdahulu juga memperkuat data yang dituliskan oleh peneliti dalam penelitian ini. Data berasal dari berbagai sumber seperti Google Scholar, MDPI, Scielo, dan NCBI. Artikel yang dipilih kemudian diseleksi sesuai dengan kriteria yang sudah ditetapkan oleh peneliti. Adapun beberapa kriteria yaitu (1) depresi pada masyarakat perkotaan dalam menghadapi pandemi COVID-19, (2) masyarakat perkotaan yang dimaksud dapat berasal dari latar belakang seperti pelajar, pasien, tenaga medis, pekerja kantoran, dan lain-lain. Artikel yang tidak sesuai dengan kriteria dan tujuan penelitian kemudian dihapus dan melakukan pembahasan dan analisis untuk artikel yang sesuai dengan penelitian ini.

\section{HASIL PEMBAHASAN}

Terdapat kriteria dalam menentukan literatur pada studi ini, yaitu literatur yang membahas depresi di antara populasi umum dalam masyarakat perkotaan selama pandemi COVID-19. Dalam hal ini, literatur yang tidak terkait, studi tanpa data yang memadai, studi intervensi, maupun metode yang tidak jelas, tidak digunakan oleh peneliti karena tidak sesuai. Dalam pencarian data literatur, peneliti mendapatkan 14 artikel yang membahas dan sesuai dengan kriteria.

Berdasarkan 14 artikel tersebut, didapatkan hasil bahwa depresi pada masyarakat perkotaan dalam menghadapi pandemi COVID-19 disebabkan oleh beberapa faktor. Faktor-faktor tersebut meliputi usia, jenis kelamin, pekerjaan, demografis, keuangan, psikologis, relasi dan aktivitas yang tercantum dalam Tabel 1 .

Dalam beberapa bulan saja, pandemi COVID-19 telah menyebar dan menciptakan keadaan darurat secara mendunia. Oleh karena itu pemerintah melakukan tindakan pencegahan dengan menutup tempat kerja, sekolah, maupun universitas untuk meminimalkan kontak masyarakat. Tidak hanya itu, pembatasan masuk atau keluar dan penerapan kewajiban memakai masker pada suatu daerah dilakukan sebagai langkah preventif. Dengan adanya pembatasan sosial, kegiatan masyarakat dan akses sosial kini menjadi terbatas, hal inilah yang dapat menimbulkan tekanan bagi masyarakat (Setyaningrum \& Yanuarita, 2020). 
Tabel 1. Faktor yang Menimbulkan Depresi pada Masyarakat Perkotaan Selama Pandemi COVID Faktor Dampak saat Pandemi COVID-19

Usia

- Kelompok umur kurang dari 35 tahun lebih sering mengalami kecemasan dan gejala depresi (Huang \& Zhao, 2020).

- Remaja lebih sering merasakan perasaan sedih atau depresi selama COVID-19 (Barros et al., 2020).

- Individu yang termasuk kedalam kelompok umur tua memiliki tingkat depresi yang lebih rendah dibandingkan individu yang lebih muda (Alsharji, 2020).

Jenis Kelamin

- Perempuan cenderung lebih sering merasakan sedih atau depresi saat pandemi COVID-19 (Barros., dkk, 2020)

- Perempuan dengan rentang umur 18-29 tahun memiliki tingkat depresi yang lebih tinggi (Ustun, 2020).

- Perempuan secara signifikan memiliki tingkat depresi lebih tinggi selama pandemi COVID-19 (Hyland et al., 2020).

Pekerjaan

- Tenaga medis lebih sering mengalami kecemasan dan gejala depresi (Huang \& Zhao, 2020).

- Individu yang melakukan pekerjaan sukarelawan cenderung mengalami gejala depresi (Barrera et al., 2020).

- Individu yang tidak bisa melakukan pekerjaan dengan sistem work from home

- Pelajar dalam penelitian Ustun (2020) memiliki tingkat depresi yang lebih tinggi.

Demografi

- Tinggal di perkotaan lebih tinggi kemungkinannya untuk mengalami depresi selama pandemic (Özdin \& Özdin, 2020).

- Individu yang tinggal di apartemen tanpa balkon cenderung mengalami gejala depresi (Barrera et al., 2020).

- Tinggal di lingkungan yang kurang beruntung secara sosial ekonomi akibat beban yang semakin tidak seimbang akibat pandemi bisa menimbulkan gejala depresi (Yong dan Xiang., 2021).

Keuangan

- Pemasukan yang lebih rendah dan memiliki tabungan kurang dari $\$ 5000$ ( $\pm R P 70.150 .000$ ) bisa meningkatkan resiko gejala depresi (Abdalla et al., 2020).

- Kehilangan pendapatan bisa menjadi salah satu penyebab munculnya depresi selama pandemic (Hyland et al., 2020).

Psikologis

- Adanya pandemi COVID-19 meningkatkan prevalensi gejala depresi sebanyak tiga kali lipat di Amerika Serikat (Abdalla et al., 2020).

- Kekhawatiran terinfeksi virus COVID-19 dan kurangnya masker medis yang dimiliki bisa memunculkan depresi, kecemasan dan memburuknya kesehatan mental (Choi, Hui \& Wan, 2020).

- Selama karantina, perilaku kompulsif penggunaan internet, media sosial, dan adiksi game yang meningkat berkorelasi positif dengan kesepian dan depresi pada remaja (Biswas et al., 2020) .

Relasi

- Gejala depresi lebih sering dialami oleh individu yang sudah menikah (Alsharji, 2020).

- Menghabiskan waktu dengan keluarga, dan menyibukan diri dengan kegiatan sekolah atau kerja di rumah bisa menurunkan tingkat depresi yang dimiliki individu di perkotaan (Ustun, 2020).

- Gejala depresi dan optimisme yang rendah muncul pada individu yang tinggal seorang diri, memiliki tanggungan merawat anggota keluarga dan menjadi bagian dari minoritas (Fisher, Jane RW, et al., 2020).

- Mengetahui orang terdekat dikonfirmasi/dicurigai terkena COVID-19 mampu menimbulkan gejala depresi (Hyland et al., 2020).

- Memiliki keluarga atau teman dengan mental illness menjadi salah satu faktor resiko munculnya depresi pada remaja selama pandemi (Sabei et al., 2020).

- Perubahan negatif pada aktivitas fisik, tidur, merokok dan mengonsumsi alkohol berlebih cenderung membuat individu mengalami depresi, kecemasan dan stress yang lebih tinggi (Stanton, To, dkk., 2020).

- Individu yang melakukan aktivitas fisik lebih banyak cenderung lebih rendah mengalami gejala depresi (Alsharji, 2020). 
Selain itu, tidak hanya menimbulkan perhatian terhadap kesehatan, pandemi COVID-19 juga menyebabkan sejumlah gangguan psikologis dan mental seperti depresi pada masyarakat di daerah perkotaan. Selaras dengan penelitian Özdin \& Özdin (2020), individu yang tinggal di area perkotaan memungkinkan adanya tingkat depresi lebih tinggi. Berdasarkan hasil dari beberapa data literatur, peneliti menganalisis bahwa terdapat tekanan psikologis yang muncul akibat pandemi COVID-19 pada masyarakat perkotaan dikarenakan beberapa kekhawatiran seperti khawatir apabila terinfeksi COVID-19, tidak memiliki cukup masker, dan tidak sanggup bekerja dari rumah (Choi, Hui \& Wan, 2020).

Tingkat depresi yang tinggi juga dapat disebabkan oleh status pekerjaan individu. Individu yang memiliki pekerjaan sebagai tenaga medis, individu yang kehilangan pekerjaan dan individu yang memiliki pendapatan rendah maupun menurun akibat pandemi COVID-19 memiliki risiko tingkat depresi yang lebih tinggi (Huang \& Zhao, 2020; Fisher, Jane RW, et al., 2020; Abdalla, et al., 2020; Hyland, et al., 2020; Ustun, 2020). Tidak hanya status pekerjaan, status perkawinan pun menjadi faktor meningkatnya depresi. Seseorang yang lajang akan lebih sering menghabiskan waktunya dengan menggunakan media sosial daripada yang individu yang telah menikah maupun fokus dengan pekerjaannya. Mereka sering mendapatkan informasi yang berlebihan dan tidak akurat yang memungkinkan memicu depresi (Ustun, 2020).

Studi ini juga menunjukkan bahwa tingkat depresi yang tinggi dipengaruhi oleh jenis kelamin dan usia individu. Penelitian yang dilakukan Huang \& Zhao (2020) dan Ustun (2020) memaparkan bahwa individu yang lebih muda yang berusia 18-35 tahun lebih menunjukkan gejala depresi daripada orang tua. Menurut Vibriyanti (2020), perempuan dan remaja dapat sangat rentan terkena gangguan psikologis dan mental selama pandemi COVID-19, yang mana hal tersebut dibuktikan oleh beberapa penelitian yang telah dilakukan (Barros et al., 2020; Barrera, et al., 2020; Biswas, et al., 2020; Omari, et al., 2020; Alsharji, 2020; Hyland et al., 2020; Ustun, 2020; Fisher, Jane RW et al., 2020). Dari penelitian tersebut menunjukkan bahwa perbedaan jenis kelamin terhadap tingkat depresi ini dikarenakan perempuan lebih sensitif terhadap masalah psikologis dan kesehatan mental sehingga rentan mengalami depresi dibandingkan laki-laki.

Sedangkan pada remaja, tingginya tingkat depresi dikarenakan adanya pemberlakuan isolasi sosial yang menyebabkan para remaja memiliki kecanduan terhadap penggunaan internet. Mamun et al., (2020) menyatakan bahwa kecanduan internet meningkatkan kemungkinan gejala kecemasan dan depresi. Hasil dari penelitian Biswas et al., (2020), menunjukkan bahwa remaja yang menghabiskan waktu di media sosial dan bermain game selama isolasi sosial memiliki kualitas tidur yang buruk dan dapat menimbulkan gangguan psikologis selama pandemi COVID-19.

\section{KESIMPULAN}

Pada masa pandemi akibat covid-19 ini memberikan banyak dampak negatif pada masyarakat perkotaan yang dapat mengakibatkan terganggunya atau munculnya gejala-gejala pada kesehatan mental mereka. Banyaknya perubahan dan batasan-batasan yang diberikan pemerintah menjadi salah satu penyebab meningkatnya tingkat depresi yang terjadi di masyarakat seperti harus melakukan social distancing yang membatasi ruang gerak mereka, harus bekerja dari rumah, banyak individu yang harus diberhentikan dari tempat kerjanya khususnya mereka yang masih memiliki tanggung jawab untuk memenuhi kebutuhan, juga individu-individu yang harus merasakan karantina mandiri dan juga lockdown di daerah tempat tinggalnya. Hal-hal tersebut juga dapat mempengaruhi sistem perekonomian serta kegiatan sosial yang ada dalam masyarakat menjadi terhambat dan sangat merugikan mereka. Selain itu kekhawatiran yang berlebihan akibat takut jika terdampak COVID-19 juga keterbatasan alat medis seperti masker, disinfectant, hand sanitizer dan lain-lain juga mempengaruhi tingkat kecemasan, stress dan depresi pada individu. Peningkatan depresi berdasarkan studi literatur yang telah dikumpulkan, lebih banyak terjadi pada individu yang masih remaja khususnya perempuan.

Semenjak wabah virus ini menjadi penyakit yang berbahaya dan dampaknya 
secara luas terjadi di berbagai aspek terutama pada kondisi kesehatan masyarakat baik secara fisik maupun psikis. Maka dari itu, disarankan kepada masyarakat untuk selalu berusaha berpikir secara positif, menaati protokol demi membantu memutuskan rantai penyebaran COVID-19, serta mengelola stress dengan melakukan aktivitas yang positif seperti berolahraga dan sebagainya agar terhindar dari depresi selama menghadapi masa pandemi. Selain itu, diharapkan pihak pemerintah tidak hanya fokus pada penanganan COVID-19 secara fisik, namun perlu memberikan langkah yang preventif dan bersifat psiko edukatif untuk keadaan psikis masyarakat dalam menghadapi pandemi virus corona.

\section{DAFTAR PUSTAKA}

Alsharji, E. K. (2020). Anxiety and depression during the covid-19 pandemic in Kuwait: the importance of physical activity. Middle east current psychiatry. https://doi.org.10.1186/s43045-02000065-6

Ayuningtyas, D., Misnaniarti, M., \& Rahyani, M. (2018). Analisis Situasi Kesehatan Mental pada Masyarakat di Indonesia dan Strategi Penanggulangannya. Jurnal IImu Kesehatan Masyarakat, 9(1). https://doi.org/10.26553/jikm.2018.9.1.1$\underline{10}$

Barros, M., Lima, M., Malta, D., Szwarcwald., \& et al. (2020). Report on sadness/depression, nervousness/anxiety and sleep problems in the Brazilian adult population during the covid-19 pandemic. doi:10.1590/S1679-49742020000400018

Choi, H. P. E., Hui, H. P. B., \& Wan, F. Y. E. (2020). Depression and anxiety in Hong Kong during covid-19. International journal of environmental research and public health, $17, \quad 3740$. doi:10.3390/ijerph17103740

Ettman CK, Abdalla SM, Cohen GH, Sampson L, Vivier PM, Galea S. Prevalence of Depression Symptoms in US Adults Before and During the COVID19 Pandemic. JAMA Netw Open. 2020;3(9):e2019686. doi:10.1001/jamanetworkopen.2020.1968 $\underline{6}$

Fernandes, B., Biswas, N. U., Mansukhani, T. R., Vallejo, A., \& Essau, A. C. (2020). The impact of covid-19 lockdown on internet use and escapism in adolescents. Revista de psicología clínica con niños y adolescentes, vol.7, pp 59-65.

Fisher, J. R., Tran, T. D., Hammarberg, K., Sastry, J., Nguyen, H., Rowe, H., \& Kirkman, M. (2020). Mental health of people in Australia in the first month of COVID-19 restrictions: a national survey. The Medical Journal of Australia, 1.

Huang, Y., Zhao, N. (2020). Chinese mental health burden during the covid-19 pandemic. Asian journal of psychiatry. https://doi.org/10.1016/i.ajp.2020.102052

Hyland, P., Shevlin, M., McBride, O., Murphy, J., Karatzias, T., Bentall, R.P.F. (2020). Anxiety and depression in the Republic of Ireland during the COVID-19 pandemic. Acta Psychiatrica Scandinavica, 1-8. DOI: $\underline{10.1111 / \text { acps. } 13219}$

Mamun, M. A., Hossain, M. S., Moonajilin, M. S., Masud, M. T., Misti, J. M., \& Griffiths, M. D. (2020). Does loneliness, self-esteem and psychological distress correlate with problematic internet use? A Bangladeshi survey study. Asia-Pacific Psychiatry, 12(2).https://doi.org/10.1111/appy.12386

Omari, A. O., Sabei, A. S., Rawajfah, A. O., Sharour, A. L., Aljohani, K., Alomari, K., Shkman, L. Dameery, A. K., Saifan, A., Zubidi, A. B., Anwar, S., \& Alhalaiqa, F. (2020). Prevalence and predictors of depression, anxiety, and stress among youth at the time of covid-19: an online cross-sectional multicountry study. Hindi: depression research and treatment. https://doi.org/10.1155/2020/8887727

Özdin, S., \& Özdin, Ş. B. (2020). Levels and predictors of anxiety, depression and health anxiety during COVID-19 pandemic in Turkish society: The importance of gender. International Journal of Social Psychiatry, 1-8. https://doi.org/10.1177/002076402092705 1 https://doi.org/10.1177/00207640209270 
Stanton, R., To, Q. G., Khalesi, S., Williams, S. L., Alley, S. J., Thwaite, T. L., Fenning, A. S., \& Vandelanotte, C. (2020). Depression, Anxiety and Stress during COVID-19: Associations with Changes in Physical Activity, Sleep, Tobacco and Alcohol Use in Australian Adults. International Journal of Environmental Research and Public Health, 17(11). doi:10.3390/ijerph17114065

Setyaningrum, W., Yanuarita, H. A. (2020). Pengaruh covid-19 terhadap kesehatan mental masyarakat di Kota Malang. Jurnal ilmu sosial dan pendidikan, vol.4(4). http://ejournal.mandalanursa.org/index.ph $\mathrm{p} / \mathrm{JISIP} /$ index

Susilo, A., Rumende, C. M., Pitoyo, C. W., Santoso, W., D., Yulianti, M., Herni Kurniawan., \& Sinto, R. (2020). Coronavirus disease 2019: review of current literatures. Jurnal penyakit dalam Indonesia, vol.7(1).
Tamarit, A., Barrera, U., Monaco, E., Schoeps, K., \& Castilla, I. M. (2020). Psychological impact of covid-19 pandemic in Spanish adolescents: risk and protective factors of emotional symptoms. Revista de psicología clínica con niños y adolescentes, vol.7, pp 73-80.

Ustun, G. (2020). Determining Depression and Related Factors in A Society Affected by COVID-19 Pandemic. The International Journal of Social Psychiatry.

Vibriyanti, D. (2020). Kesehatan Mental Masyarakat: Mengelola Kecemasan di Tengah Pandemi COVID-19. Jurnal Kependudukan Indonesia, 69-74. 